\title{
INDEKS OVERLAP DAN SINKRONISASI PEMBUNGAAN DALAM KEBUN BENIH KAYUPUTIH (Melaleuca cajuputi) DI PALIYAN, GUNUNGKIDUL
}

Overlapping index and flowering synchrony in Cajuput (Melaleuca cajuputi) seed orchard at Paliyan, Gunungkidul

\author{
Noor Khomsah Kartikawati \\ Balai Besar Penelitian Bioteknologi dan Pemuliaan Tanaman Hutan \\ Jl. Palagan Tentara Pelajar Km. 15, Purwobinangun, Pakem, Sleman, Yogyakarta, Indonesia \\ e-mail: aticka_kart@yahoo.com
}

Tanggal diterima : 4 Juni 2015, Tanggal direvisi : 15 Juni 2015, Disetujui terbit : 1 September 2015

\begin{abstract}
Flowering synchrony will support the extent of random mating among families and hence the genetic gain in the resultant progeny. In the study, synchrony among families for flowering and peak flowering was estimated through the phenogram as well as the overlapping index. Research was carried out at cajuput (Melaleuca cajuputi sub species cajuputi) seed orchard in two flowering periods (2010 and 2011) at Paliyan, Gunungkidul. The observation results showed that peak flowering occurred in the middle of January and more than 75\% families in cajuput seed orchard have the same flowering time. More than 90\% families have overlapping index value greater than 0.8 in contrast to 2 families originated from Western and Northern Australia which revealed very low $(<0.6)$ overlapping index. Seeds harvested from the cajuput seed orchard showed high genetic potencial, as $75 \%$ trees in Paliyan seed orchard produced seeds simultaneusly.
\end{abstract}

\section{Keywords: index overlapping, flowering synchrony, Cajuput, Melaleuca cajuputi, seed orchard}

\begin{abstract}
ABSTRAK
Salah satu aspek penting di kebun benih adalah informasi tentang sinkronisasi pembungaan. Pembungaan yang sinkron mendukung terjadinya perkawinan silang secara acak sehingga perolehan genetik yang dihasilkan dapat optimal. Penelitian tentang sinkronisasi pembungaan dilakukan di kebun benih kayuputih di Paliyan, Gunungkidul, berdasarkan fenogram dan indeks overlap selama 2 periode pembungaan (2010-2011). Hasil penelitian menunjukkan lebih dari $75 \%$ famili penyusun di kebun benih memiliki pembungaan yang sinkron dengan puncak pembungaan terjadi pada akhir Januari sampai awal Februari. Sebanyak 90\% famili memiliki nilai indeks overlap lebih dari 0,8 meskipun terdapat juga 2 famili dari Australia bagian barat dan Australia bagian utara yang memiliki nilai indeks overlap sangat rendah $(<0,6)$. Sebagai implikasinya adalah bahwa benih yang dihasilkan dari kebun benih kayuputih di Paliyan mempunyai potensi genetik yang bagus karena merupakan hasil produksi dari 75\% pohon-pohon di kebun benih Paliyan.
\end{abstract}

Kata kunci: indeks overlap, sinkronisasi pembungaan, Kayuputih, Melaleuca cajuputi, kebun benih

\section{PENDAHULUAN}

Program pemuliaan Melaleuca cajuputi subsp cajuputi telah dirintis sejak tahun 1995 dan ditujukan untuk meningkatkan rendemen serta kadar 1,8 cineole dari daun kayuputih.
Kerjasama antara Balai Besar Penelitian Bioteknologi dan Pemuliaan Tanaman Hutan Yogyakarta dengan CSIRO Australia telah berhasil melakukan serangkaian kegiatan pemuliaan pohon, mulai dari pengumpulan materi genetik dari 
sebaran alami kayuputih, pembangunan uji keturunan, evaluasi dan seleksi genetik, serta pembangunan kebun benih. Sampai saat ini telah terbangun 3 kebun benih kayuputih hasil konversi dari uji keturunan yang terdapat di Paliyan, Ponorogo dan Cepu.

Pembangunan kebun benih ditujukan untuk menghasilkan benih-benih yang telah termuliakan secara genetik dengan kualitas dan kuantitas yang memadai. Dengan demikian pemanfaatan benih unggul untuk penanaman dalam skala luas dapat dilakukan dengan hasil/produktivitas yang sesuai dengan peningkatan genetik yang telah diprediksi. Namun, fenomena yang sering ditemukan di lapangan adalah adanya kegagalan pada kebun benih untuk menghasilkan benih unggul baik dalam kuantitas maupun kualitasnya. Sebagai upaya untuk mempertahankan perolehan genetik (genetic gain) yang telah dihasilkan melalui program pemuliaan, maka manajemen di dalam kebun benih harus mempertimbangkan berbagai faktor untuk menghasilkan benih unggul (Moncur \& Bolland, 2000). Banyak pemulia yang telah melakukan pengamatan pada kebun benih dan meyakini bahwa manipulasi lingkungan seperti pengaturan jarak tanam, pemberian pupuk dan hormon, pengendalian gulma merupakan aspek penting di kebun benih yang berperan dalam menentukan produksi benih. Namun demikian terdapat aspek lain yang tidak kalah pentingnya, yaitu tentang sinkronisasi pembungaan di dalam kebun benih.

Pengetahuan tentang pembungaan dan pembuahan di kebun benih sangat penting dalam manajemen kebun benih, terutama kaitannya dalam mengoptimalkan kualitas genetik dan keragaman genetik dari benih yang dihasilkan (Kassaby, 2000; Burczyk \& Chalupka, 1997). Sinkronisasi pembungaan merupakan salah satu persyaratan kondisi ideal di dalam kebun benih. Mengingat materi yang digunakan dalam pembangunan kebun benih berasal dari provenan yang berbeda-beda maka ada kemungkinan adaptasi dari masing-masing individu juga akan berbeda, termasuk dalam pola pembungaannya.

Penelitian ini bertujuan untuk mendapatkan informasi sinkronisasi pembungaan dan nilai indeks overlap di kebun benih dalam memproduksi bunga dan buah pada kebun benih kayuputih di Paliyan, Gunungkidul.

\section{BAHAN DAN METODE}

\section{A. Lokasi dan materi penelitian}

Penelitian dilakukan di kebun benih kayuputih di Paliyan, Gunungkidul. Letak geografis kebun benih tersebut adalah 759'10,4'LS dan 110²9'10,8’BT. Lokasi ini terdapat pada ketinggian $150 \mathrm{~m}$ di atas 
permukaan laut. Iklim termasuk tipe $\mathrm{C}$ menurut Schmidt dan Ferguson, dengan curah hujan rerata $2.100 \mathrm{~mm}$ per tahun (Dinas Pertanian Tanaman Pangan dan Perikanan, 2010). Kebun benih kayuputih dibangun pada tahun 1998, terdiri dari 19 famili, 10 blok dan 10 pohon per plot dengan jarak tanam $3 \mathrm{~m}$ x 1,5 m.

Materi yang digunakan dalam pembangunan kebun benih tersebut adalah benih hasil eksplorasi dari sebaran alam kayu putih di Kepulauan Maluku, Northern Teritory Australia, Western Australia, dan hutan tanaman di Gundih.

\section{B. Prosedur pelaksanaan dan variabel pengamatan}

\section{Pengamatan}

Penelitian pembungaan dilakukan dengan mengamati waktu pembungaan sejak mulai berbunga hingga masa pembungaan berakhir, menghitung jumlah pohon yang berbunga dalam setiap pengamatan, serta mengukur tinggi dan diameter pohon.

\section{Analisis data}

Analisis varian dilakukan dengan meng-gunakan model sebagai berikut :

$\mathbf{Y}_{\mathrm{ijk}}=\mu+\operatorname{Rep}_{\mathrm{i}}+\operatorname{Prov}_{\mathrm{j}}+\operatorname{Fam}_{\mathrm{k}}\left(\operatorname{Prov}_{\mathrm{j}}\right)+\mathbf{E}_{\mathrm{ijk}}$

Keterangan :

$Y_{\mathrm{ij}} \quad$ : Pengamatan ke ij

$\mu \quad$ : Nilai rata-rata umum

Rep $_{\mathrm{i}}$ : Pengaruh ulangan ke - i

Prov $_{j}$ : Pengaruh provenan ke- $j$

Fam $_{\mathrm{k}}\left(\right.$ Prov $\left._{\mathrm{j}}\right)$ : Pengaruh famili k dalam provenan $j$
$\mathrm{E}_{\mathrm{ijk}} \quad$ : Pengaruh Error ke-ijk

Untuk mengetahui hubungan antara 2 sifat maka dihitung nilai korelasi genetiknya sesuai formula berikut :

$$
\begin{aligned}
& r A=\frac{\operatorname{Cov} A(x y)}{\sqrt{\sigma^{2} x * \sigma^{2}} y} \\
& \operatorname{Cov} A(x y)=\frac{\sigma^{2} x y-\sigma^{2} x-\sigma^{2} y}{2}
\end{aligned}
$$

Dengan $\sigma^{2} x \quad$ adalah varian komponen famili sifat $\mathrm{x} ; \sigma^{2} y$ adalah varian komponen famili sifat $y$.

Untuk data minyak (rendemen dan kadar 1,8 cineole) digunakan data sekunder dari hasil penelitian Susanto et al.(2003), yang menyebutkan bahwa rata-rata rendemen pada kebun benih kayuputih adalah 2,06\% dan rata-rata untuk kadar 1,8 cineole adalah $56,1 \%$.

Nilai indeks overlap $(C)$ dihitung berdasarkan rumus yang dikembangkan oleh Ganuga dan Vasudeva (2009) sebagai berikut :

$$
C=\frac{2 \sum_{\mathrm{i}=1}^{\mathrm{n}}(P i j \mathrm{x} P i k)}{\left(\sum P i j^{2}+\sum P i k^{2}\right)}
$$

Dengan $P i j$ adalah proporsi famili ke- $j$ pada saat pembungaan puncak pada periode tertentu i, Pik, adalah proporsi famili ke- $k$ pada saat pembungaan puncak pada periode tertentu $\mathrm{i}$, serta $\mathrm{n}$ adalah jumlah minggu selama pengamatan. 


\section{HASIL DAN PEMBAHASAN}

\section{A. Pertumbuhan, sifat minyak dan reproduksi pada kayuputih}

Hasil analisis varian terhadap pertumbuhan dan reproduksi di kebun benih kayuputih pada umur 14 tahun di Paliyan dalam dua periode pengamatan diameter menunjukkan perbedaan nyata antar famili dalam provenan. Sementara pengamatan terhadap jumlah buah terbentuk menunjukkan perbedaan nyata antar provenan pada dua periode pengamatan (Tabel 1). menunjukkan bahwa untuk tinggi, dan

Tabel.1. Hasil analisis varian pertumbuhan, jumlah bunga, buah dan buah terbentuk antar famili pada kebun benih kayuputih di Paliyan pada pengamatan periode 2010 dan 2011

\begin{tabular}{|c|c|c|c|c|c|}
\hline \multirow[b]{2}{*}{ Sumber variasi } & \multicolumn{3}{|c|}{ 2010-2011 } & \multicolumn{2}{|c|}{ 2011-2012 } \\
\hline & $\begin{array}{c}\text { Derajat } \\
\text { bebas }\end{array}$ & $\begin{array}{c}\text { Rerata } \\
\text { kuadrat }\end{array}$ & Pr $>F$ & $\begin{array}{c}\text { Rerata } \\
\text { kuadrat }\end{array}$ & $\mathbf{P r}>\mathbf{F}$ \\
\hline \multicolumn{6}{|l|}{ A. Tinggi } \\
\hline Replikasi & 9 & 17,972 & $<0,0001 * *$ & 18,782 & $<0,0001 * *$ \\
\hline Provenan & 8 & 368,45 & $0,035^{*}$ & 423.732 & $0,043 *$ \\
\hline Famili(Provenan) & 152 & 2.654 & $0,001 * *$ & 2,876 & $0,001 * *$ \\
\hline \multicolumn{6}{|l|}{ B. Diameter } \\
\hline Replikasi & 9 & 155,921 & $<0,0001^{* *}$ & 165,932 & $<0,0001^{* *}$ \\
\hline Provenan & 8 & $2.398,245$ & $0,045 *$ & $2.395,62$ & $0,056 \mathrm{~ns}$ \\
\hline Famili(Provenan) & 152 & 18,267 & $0,546 \mathrm{~ns}$ & 18,657 & $0,645 \mathrm{~ns}$ \\
\hline \multicolumn{6}{|l|}{ C. Jumlah Bunga } \\
\hline Replikasi & 9 & $3.038 .290,7$ & $0,9704 \mathrm{~ns}$ & $3.122 .604,73$ & $0,4764 \mathrm{~ns}$ \\
\hline Provenan & 8 & $26.899 .410,6$ & $0,0235 *$ & $2.619 .284,62$ & $0,6960 \mathrm{~ns}$ \\
\hline Famili(Provenan) & 152 & $115.743 .299,6$ & $0,3556 \mathrm{~ns}$ & $22.869 .319,96$ & $0,7310 \mathrm{~ns}$ \\
\hline \multicolumn{6}{|l|}{ D. Jumlah Buah } \\
\hline Replikasi & 9 & $3.026 .596,9$ & $0,9857 \mathrm{~ns}$ & $1.212 .939,36$ & $0,6849 \mathrm{~ns}$ \\
\hline Provenan & 8 & $206.097 .634,8$ & $0,0719 \mathrm{~ns}$ & $130.753,79$ & $0.7889 \mathrm{~ns}$ \\
\hline Famili(Provenan) & 152 & $64.847 .586,8$ & $0,8529 \mathrm{~ns}$ & $18.257 .580,23$ & $0.5257 \mathrm{~ns}$ \\
\hline \multicolumn{6}{|l|}{ E. Buah terbentuk } \\
\hline Replikasi & 9 & 0,10652 & $0,5498 \mathrm{~ns}$ & 0,16747 & $0.447 \mathrm{~ns}$ \\
\hline Provenan & 8 & 2,09669989 & $0,0013 * *$ & 0,20924710 & $0.0016 * *$ \\
\hline Famili(Provenan) & 152 & 0,71916226 & 0,3893 & 0,007324 & $<0,0001 * *$ \\
\hline
\end{tabular}

Keterangan : $* *$ berbeda nyata pada taraf uji $1 \%$,

* berbeda nyata pada taraf uji 5\%, ns tidak berbeda nyata

Pada pengamatan tahun 2010, terlihat famili 24 yang berasal dari Gundih menunjukkan jumlah bunga, jumlah buah jadi dan buah terbentuk yang paling besar, sedangkan ranking yang paling jelek terdapat pada famili 21 yang berasal dari Australia (Tabel 2). Hasil analisis statistik terhadap korelasi genetik untuk pertumbuhan dan reproduksi pada kebun benih kayuputih menunjukkan bahwa terdapat korelasi yang moderat/sedang antara tinggi pohon dengan buah terbentuk (fruitset) $\left(r_{g}=0,57\right)$, namun sebaliknya terdapat korelasi negatif antara diameter dengan buah terbentuk (fruitset) $\left(r_{g}=-0,17\right)$. Korelasi negatif juga ditunjukkan oleh hubungan antara rendemen dengan buah terbentuk (fruitset) $\left(r_{g}=-0,20\right)$. Griffin \& Sedgley 
(1989) menyebutkan bahwa umur, ukuran, pertumbuhan dan kondisi tempat tumbuh sangat berpengaruh terhadap reproduksi tanaman. Penyerbukan tidak menjadi faktor pembatas, keberhasilan reproduksi sangat dipengaruhi oleh ukuran tanaman (Crawley, 1997; Norghauer et al., 2015). Ini mencerminkan bahwa seleksi yang dilakukan berdasarkan tinggi pohon mengindikasikan makin tinggi pohon produksi benih yang dihasilkan makin banyak. Secara fisiologis, pohon yang lebih tinggi akan mendapatkan sinar matahari yang lebih banyak, karena tidak tertutup oleh tajuk pohon yang lain. Kelimpahan sinar matahari ini memberikan pengaruh yang positif bagi pertumbuhan generatif pada tanaman. Jika ditinjau dari umur fisiologisnya, tajuk pohon merupakan bagian tanaman dengan umur fisiologis paling tua. Semakin jauh bagian tanaman dari permukaan tanah, maka umur fisiologisnya semakin matang, sehingga akan memproduksi biji lebih banyak.

Tabel 2. Rata-rata famili diameter, tinggi pohon, jumlah bunga, jumlah buah dan buah terbentuk pada kebun benih kayuputih (pengamatan pada puncak pembungaan 2010)

\begin{tabular}{llrrrrr}
\hline Famili & \multicolumn{1}{c}{ Provenan } & $\begin{array}{c}\text { Diameter } \\
(\mathbf{c m})\end{array}$ & $\begin{array}{c}\text { Tinggi } \\
(\mathbf{c m})\end{array}$ & $\begin{array}{c}\text { Jumlah } \\
\text { bunga }\end{array}$ & $\begin{array}{c}\text { Jumlah } \\
\text { buah }\end{array}$ & $\begin{array}{c}\text { Buah } \\
\text { Terbentuk }\end{array}$ \\
\hline 1 & Rat gelombang, Buru & 17,98 & 9,09 & 1603 & 869 & 0,54 \\
2 & Masarete, Buru & 14,13 & 7,51 & 3267 & 2081 & 0,63 \\
3 & Rat gelombang, Buru & 14.29 & 7,82 & 3121 & 1927 & 0,61 \\
5 & Masarete, Buru & 13.00 & 7,25 & 2769 & 1595 & 0,57 \\
8 & Waipirit, Seram & 14,23 & 7,65 & 1236 & 494 & 0,39 \\
9 & Pelita Jaya, Seram & 16.01 & 8,12 & 4109 & 1898 & 0,46 \\
10 & Pelita Jaya, Seram & 13.15 & 8,90 & 773 & 455 & 0,58 \\
11 & Pelita Jaya, Seram & 14.95 & 7,98 & 2017 & 1333 & 0,66 \\
12 & Cotonea, Seram & 13,59 & 7,86 & 3006 & 1893 & 0,62 \\
13 & Cotonea, Seram & 13.15 & 7,75 & 2401 & 1505 & 0,62 \\
14 & Cotonea, Seram & 14.93 & 8,61 & 1287 & 720 & 0,55 \\
18 & Suli, Ambon & 12.69 & 6,75 & 2442 & 1533 & 0,62 \\
19 & Northern Australia & 16.23 & 7,97 & 396 & 120 & 0,30 \\
20 & Northern Australia & 14.00 & 8,07 & 198 & 106 & 0,53 \\
21 & Western Australia & 11.12 & 6,52 & 0 & 0 & 0,00 \\
22 & Western Australia & 15.29 & 6,58 & 443 & 204 & 0,46 \\
23 & Western Australia & 14.17 & 6,74 & 1881 & 1197 & 0,63 \\
24 & Gundih, Jawa Tengah & 15.49 & 9,66 & 6171 & 4488 & 0.72 \\
25 & Masarete, Buru & 16.03 & 8,21 & 3102 & 2162 & 0.69 \\
\hline
\end{tabular}

Dalam proses fisiologis, ketika generatifnya terhambat, begitu juga tanaman melangsungkan perkembangan sebaliknya. Menurut Levy dan Dean (1998) vegetatifnya maka perkembangan transisi dari fase vegetatif ke fase generatif 
lebih dikendalikan oleh faktor genetis stimulator yang memberikan sejumlah dibandingkan dengan faktor lingkungan. sinyal kepada tanaman (Griffin \& Sedgley, Faktor eksternal seperti cahaya, suhu, iklim 1989; Owens et al., 1991; Larcher, 1997) dan kadar nutrisi lebih berperan sebagai

Tabel.3. Rata-rata famili diameter, tinggi pohon, jumlah bunga, jumlah buah dan buah terbentuk pada kebun benih kayuputih (pengamatan pada puncak pembungaan 2011)

\begin{tabular}{|c|c|c|c|c|c|c|}
\hline Famili & Provenan & Diameter & Tinggi & $\begin{array}{c}\text { Jumlah } \\
\text { bunga }\end{array}$ & $\begin{array}{c}\text { Jumlah } \\
\text { buah }\end{array}$ & $\begin{array}{c}\text { Buah } \\
\text { Terbentuk }\end{array}$ \\
\hline 1 & Rat gelombang, Buru & 18,31 & 9,24 & 2.020 & 733 & 0,36 \\
\hline 2 & Masarete, Buru & 14,52 & 7,67 & 2.661 & 1465 & 0,55 \\
\hline 3 & Rat gelombang, Buru & 15,07 & 7,90 & 1.795 & 751 & 0,41 \\
\hline 5 & Masarete, Buru & 13,25 & 7,35 & 2.004 & 797 & 0,39 \\
\hline 8 & Waipirit, Seram & 15,01 & 7,71 & 1.502 & 601 & 0,40 \\
\hline 9 & Pelita Jaya, Seram & 16,31 & 8,25 & 2.211 & 871 & 0,39 \\
\hline 10 & Pelita Jaya, Seram & 13,86 & 9,12 & 1.111 & 395 & 0,35 \\
\hline 11 & Pelita Jaya, Seram & 15,49 & 8,05 & 1.485 & 563 & 0,37 \\
\hline 12 & Cotonea, Seram & 14,11 & 7,95 & 1.296 & 607 & 0,46 \\
\hline 13 & Cotonea, Seram & 13,36 & 7,95 & 1.928 & 874 & 0,45 \\
\hline 14 & Cotonea, Seram & 15,29 & 8,89 & 1.873 & 863 & 0,46 \\
\hline 18 & Suli, Ambon & 13,19 & 6,96 & 1.282 & 623 & 0,48 \\
\hline 19 & Northern Australia & 16,52 & 8,11 & 113 & 25 & 0,22 \\
\hline 20 & Northern Australia & 14,34 & 8,28 & 0 & 0 & 0 \\
\hline 21 & Western Australia & 11,40 & 6,87 & 0 & 0 & 0 \\
\hline 22 & Western Australia & 15,83 & 6,69 & 0 & 0 & 0 \\
\hline 23 & Western Australia & 14,81 & 6,87 & 3.821 & 2.584 & 0,67 \\
\hline 24 & Gundih, Jateng & 16,29 & 9,99 & 2.025 & 1.300 & 0,64 \\
\hline 25 & Masarete, Buru & 16,51 & 8,43 & 3.696 & 2.619 & 0,70 \\
\hline
\end{tabular}

Secara umum spesies tanaman tropis cenderung untuk melakukan perkembangan pada musim kemarau karena kadar air menjadi faktor pembatas (Larcher, 1997). Namun demikian yang terjadi pada tanaman kayuputih di Gunungkidul adalah sebaliknya. Pengamatan pada kebun benih di Gunungkidul menunjukkan bahwa pembungaan kayuputih dimulai pada peralihan musim kemarau ke musim hujan (November) dan puncak pembungaan terjadi pada bulan Januari dengan jumlah malai mencapai 16.014 (pengamatan 2010). Ada dugaan perilaku pembungaan ini terkait dengan sifat kayuputih yang toleran terhadap genangan air. Hal yang sama dilaporkan oleh Varghese et al. (2009) pada Eucalyptus camadulensis di Panampally, India yang menghasilkan jumlah bunga lebih banyak di musim hujan dibandingkan dengan musim kering. 


\section{B. Sinkronisasi pembungaan dan intensitas pembungaan di kebun benih Kayuputih di Paliyan}

Sinkronisasi pembungaan di antara pohon-pohon dalam suatu populasi merupakan kunci awal sebuah keberhasilan reproduksi suatu tanaman (Mahoro, 2002; Chen et al., 2011). Hasil pengamatan terhadap sinkronisasi pembungaan kayuputih selama 2 periode pembungaan 2010 dan 2011 pada kebun benih kayuputih Paliyan menunjukkan terdapat persamaan waktu mulai berbunga namun terdapat perbedaan pada masa pembungaan akhir. Pada pengamatan tahun 2010, pembungaan telah dimulai pada pertengahan bulan November 2010 dan berakhir pada Juni akhir (2011). Sementara pada pengamatan kedua (2011) menunjukkan waktu awal berbunga lebih lambat (Desember). Secara umum sebagian besar (70-89\%) menunjukkan adanya waktu yang bersamaan dalam memproduksi bunga. Namun demikian masing-masing individu menampakkan waktu mulai berbunga yang berbeda-beda, meskipun berasal dari provenan yang sama. Famili-famili yang berasal dari Australia cenderung menunjukkan keterlambatan dalam berbunga. Hasil pengamatan sinkronisasi pembungaan selama 2 periode dapat dilihat pada Gambar 1 dan Gambar 2.

Selama 2 periode pengamatan pola pembungaan tampak sama. Famili-famili yang berasal dari provenan yang sama cenderung memiliki waktu pembungaan yang sama, kecuali famili-famili provenan dari Australia bagian barat. Famili 23 yang berasal dari Australia bagian barat menunjukkan proses adaptasi yang berbeda dan memiliki pola pembungaan yang serentak dengan famili dari provenan lain.

Secara umum terdapat sinkronisasi masa pembungaan yang cukup lama pada kebun benih kayuputih. Fenomena ini sangat mendukung untuk terjadinya perkawinan secara acak sehingga peluang untuk mendapatkan benih dari perkawinan silang antar pohon-pohon di kebun benih lebih besar. Sebaliknya, kondisi pembungaan yang tidak sinkron di kebun benih dapat membawa dampak buruk seperti penurunan potensi genetik dan penurunan keragaman genetik (Gomory et al., 2003; Ertekin, 2010)

Meskipun demikian, pada beberapa famili menunjukkan masa pembungaan yang tidak serentak, baik yang lebih awal maupun lebih akhir berbunga. Hal ini dapat menyebabkan peluang terjadinya perkawinan kerabat (inbreeding) atau perkawinan sendiri (selfing). Seperti yang teramati pada famili 24 pada semua replikasi yang memiliki pembungaan lebih awal (mulai berbunga pada November 2010) mendahului semua famili yang lain. Di sisi lain, kondisi yang demikian juga memungkinkan terjadinya penyerbukan 
silang dengan pohon lain di luar kebun benih yang sinkron waktu pembungaannya. Sementara itu pembungaan yang lebih lambat juga teramati misalnya famili-famili 19, 20, 21, dan 22 yang berasal dari Australia. Masa pembungaan yang sangat pendek (misalnya famili 21) dapat menyebabkan terjadinya perkawinan secara tidak acak akibat masa berbunga yang tidak bersamaan, baik karena lebih lambat atau lebih awal. Pohon-pohon yang berbunga lebih awal atau lebih akhir berpotensi diserbuki oleh pohon-pohon lain diluar area kebun benih sehingga memungkinkan terjadinya kontaminasi polen dari luar (Kang \& Lindgren, 1998; Kaya et al., 2006).

Dalam dua periode pembungaan famili-famili yang berasal dari Gundih, Jawa Tengah menunjukkan jumlah bunga, buah yang tertinggi, selain itu juga waktu mulai berbunga yang lebih cepat dibandingkan dengan famili-famili lainnya. Famili-famili yang berasal dari kepulauan Ambon, berbunga lebih lambat jika dibandingkan dengan provenan dari Gundih. Famili 23 yang berasal dari Waterbank, Australia bagian barat menunjukkan pola pem-bungaan yang spesifik dibandingkan dengan famili lain dari provenan yang sama. Famili 23 berbunga lebih awal yang hampir serentak dengan famili dari provenan Gundih dan Ambon, dengan jumlah bunga dan buah yang cukup tinggi di semua replikasi. Sebaliknya famili lain yang berasal dari Australia menunjukkan waktu mulai berbunga paling lambat dan jumlah bunga dan buah yang paling rendah.

\section{Indeks overlap}

Nilai indeks overlap mencerminkan probabilitas 2 (dua) individu untuk melakukan perkawinan silang. Nilai indeks overlap adalah $0-1$. Semakin besar nilai indeks overlap berarti semakin besar peluang terjadinya perkawinan silang di antara 2 individu.

Berdasarkan Tabel 4 terlihat bahwa nilai indeks overlap baik pada tahun 2010 maupun tahun 2011 menunjukkan 95\% famili (18 famili) memiliki indeks overlap di atas 0,6. Menurut Gunaga \& Vasudeva (2009) nilai indeks overlap di atas 0,6 mencerminkan peluang yang cukup besar untuk famili tersebut dalam melakukan penyerbukan dan pembuahan dengan famili lain sehingga persen keberhasilan menghasilkan biji juga besar. Famili no 21 yang berasal dari Australia bagian barat dalam 2 periode pengamatan menunjukkan nilai indeks overlap yang sangat rendah. Rendahnya nilai ini karena masa pembungaan famili 21 yang sangat pendek serta jumlah bunga yang sangat sedikit. Berdasarkan Tabel 2 dan Tabel 3 juga terlihat bahwa jumlah buah terbentuk 


\section{(fruitset) famili 21 menempati rangking}

terendah dari semua famili yang diamati.

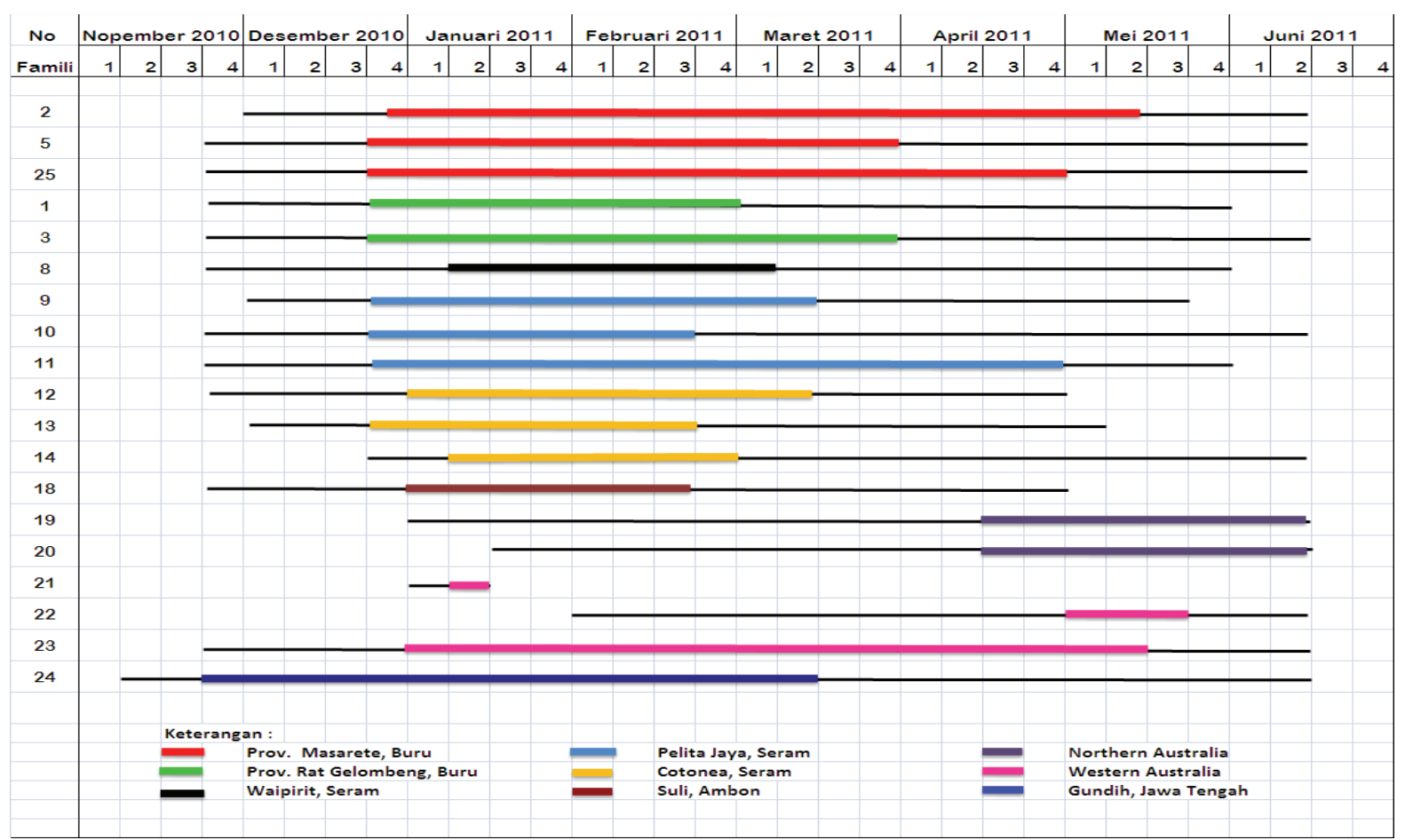

Gambar 1. Waktu pembungaan di kebun benih kayuputih di Paliyan pada bulan Nopember 2010 sampai Juni 2011. Waktu mulainya berbunga digambarkan dengan garis tipis dan waktu puncak pembungaan digambarkan dengan garis tebal. Garis tebal dengan warna sama menunjukkan provenan yang sama

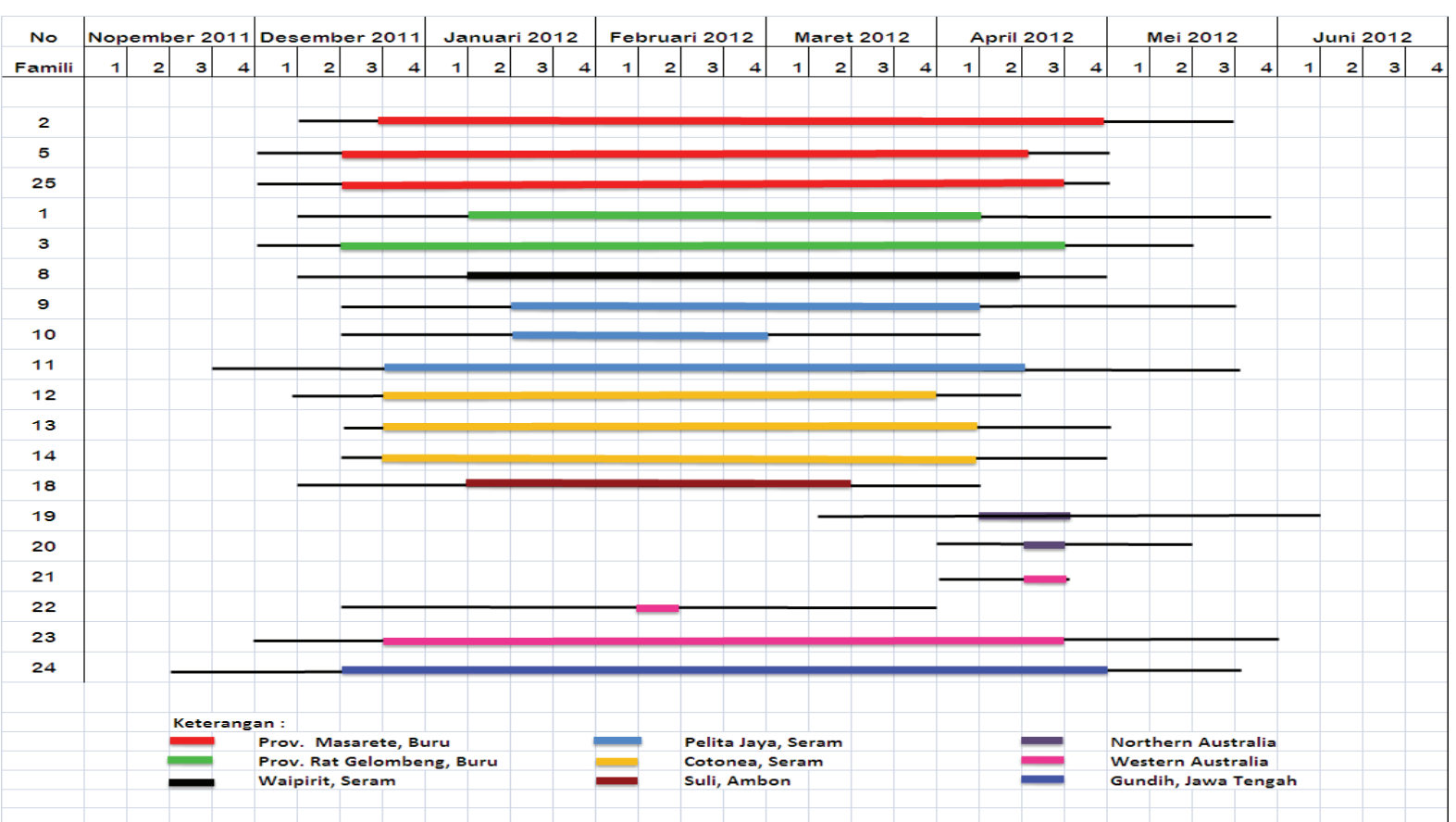

Gambar 2. Waktu pembungaan di kebun benih kayuputih di Paliyan pada bulan Nopember 2011 sampai Juni 2012. Waktu mulainya berbunga digambarkan dengan garis tipis dan waktu puncak pembungaan digambarkan dengan garis tebal. Garis tebal dengan warna sama menunjukkan provenan yang sama. 
Tabel 4. Indeks overlap pada pembungaan puncak pada kebun benih kayuputih di Paliyan, Gunung Kidul dalam periode pembungaan 2010

\begin{tabular}{|c|c|c|c|c|c|c|c|c|c|c|c|c|c|c|c|c|c|c|c|c|}
\hline & \multicolumn{20}{|l|}{ Semua } \\
\hline & Famili & 1 & 2 & 3 & 5 & 8 & 9 & 10 & 11 & 12 & 13 & 14 & 18 & 19 & 20 & 21 & 22 & 23 & 24 & 25 \\
\hline F1 & 0.830 & - & 0.798 & 0.946 & 0.817 & 0.836 & 0.945 & 0.981 & 0.899 & 0.904 & 0.875 & 0.940 & 0.883 & 0.801 & 0.806 & 0.124 & 0.826 & 0.960 & 0.792 & 0.813 \\
\hline F2 & 0.790 & & - & 0.912 & 0.970 & 0.836 & 0.853 & 0.716 & 0.960 & 0.946 & 0.944 & 0.908 & 0.945 & 0.584 & 0.492 & 0.064 & 0.510 & 0.874 & 0.947 & 0.971 \\
\hline F3 & 0.860 & & & - & 0.937 & 0.932 & 0.970 & 0.899 & 0.979 & 0.980 & 0.957 & 0.962 & 0.964 & 0.744 & 0.691 & 0.096 & 0.707 & 0.975 & 0.907 & 0.925 \\
\hline F5 & 0.822 & & & & - & 0.966 & 0.892 & 0.754 & 0.968 & 0.959 & 0.982 & 0.924 & 0.971 & 0.572 & 0.564 & 0.072 & 0.566 & 0.906 & 0.986 & 0.983 \\
\hline F8 & 0.821 & & & & & - & 0.921 & 0.775 & 0.943 & 0.956 & 0.969 & 0.918 & 0.980 & 0.552 & 0.599 & 0.088 & 0.628 & 0.935 & 0.980 & 0.971 \\
\hline F9 & 0.850 & & & & & & - & 0.909 & 0.950 & 0.966 & 0.930 & 0.936 & 0.952 & 0.688 & 0.730 & 0.118 & 0.778 & 0.977 & 0.885 & 0.900 \\
\hline F10 & 0.797 & & & & & & & - & 0.839 & 0.841 & 0.823 & 0.884 & 0.821 & 0.804 & 0.878 & 0.152 & 0.878 & 0.920 & 0.729 & 0.739 \\
\hline F11 & 0.850 & & & & & & & & - & 0.990 & 0.979 & 0.959 & 0.980 & 0.661 & 0.612 & 0.083 & 0.638 & 0.955 & 0.946 & 0.963 \\
\hline$F 12$ & 0.853 & & & & & & & & & - & 0.971 & 0.952 & 0.986 & 0.659 & 0.626 & 0.090 & 0.662 & 0.957 & 0.940 & 0.968 \\
\hline F13 & 0.846 & & & & & & & & & & - & 0.961 & 0.987 & 0.601 & 0.634 & 0.090 & 0.635 & 0.949 & 0.976 & 0.971 \\
\hline F14 & 0.846 & & & & & & & & & & & - & 0.958 & 0.669 & 0.675 & 0.093 & 0.681 & 0.967 & 0.912 & 0.922 \\
\hline F18 & 0.851 & & & & & & & & & & & & - & 0.611 & 0.626 & 0.095 & 0.647 & 0.959 & 0.972 & 0.983 \\
\hline F19 & 0.620 & & & & & & & & & & & & & - & 0.687 & 0.118 & 0.660 & 0.680 & 0.517 & 0.554 \\
\hline F20 & 0.644 & & & & & & & & & & & & & & - & 0.212 & 0.930 & 0.728 & 0.553 & 0.547 \\
\hline$F 21$ & 0.109 & & & & & & & & & & & & & & & - & 0.205 & 0.112 & 0.077 & 0.077 \\
\hline$F 22$ & 0.658 & & & & & & & & & & & & & & & & - & 0.756 & 0.568 & 0.565 \\
\hline F23 & 0.856 & & & & & & & & & & & & & & & & & - & 0.902 & 0.904 \\
\hline$F 24$ & 0.809 & & & & & & & & & & & & & & & & & & - & 0.982 \\
\hline F25 & 0.819 & & & & & & & & & & & & & & & & & & & - \\
\hline
\end{tabular}

Tabel 5. Indeks overlap pada pembungaan puncak pada kebun benih kayuputih di Paliyan, Gunung Kidul dalam periode pembungaan 2011

\begin{tabular}{|c|c|c|c|c|c|c|c|c|c|c|c|c|c|c|c|c|c|c|c|c|}
\hline & Semua & & & & & & & & & & & & & & & & & & & \\
\hline & Famili & 1 & 2 & 3 & 5 & 8 & 9 & 10 & 11 & 12 & 13 & 14 & 18 & 19 & 20 & 21 & 22 & 23 & 24 & 25 \\
\hline F1 & 0.836 & - & 0.888 & 0.974 & 0.888 & 0.911 & 0.979 & 0.971 & 0.918 & 0.920 & 0.910 & 0.952 & 0.941 & 0.690 & 0.651 & 0.033 & 0.661 & 0.963 & 0.902 & 0.890 \\
\hline F2 & 0.818 & & - & 0.950 & 0.970 & 0.974 & 0.895 & 0.890 & 0.961 & 0.976 & 0.974 & 0.863 & 0.943 & 0.527 & 0.560 & 0.024 & 0.468 & 0.891 & 0.982 & 0.982 \\
\hline F3 & 0.851 & & & - & 0.925 & 0.942 & 0.982 & 0.969 & 0.951 & 0.956 & 0.956 & 0.945 & 0.967 & 0.659 & 0.649 & 0.026 & 0.613 & 0.967 & 0.954 & 0.932 \\
\hline F5 & 0.807 & & & & - & 0.984 & 0.873 & 0.875 & 0.955 & 0.976 & 0.972 & 0.859 & 0.932 & 0.516 & 0.489 & 0.019 & 0.460 & 0.886 & 0.965 & 0.980 \\
\hline F8 & 0.827 & & & & & - & 0.901 & 0.904 & 0.979 & 0.982 & 0.964 & 0.881 & 0.963 & 0.549 & 0.544 & 0.026 & 0.488 & 0.923 & 0.977 & 0.985 \\
\hline F9 & 0.846 & & & & & & - & 0.980 & 0.925 & 0.911 & 0.916 & 0.964 & 0.959 & 0.728 & 0.720 & 0.036 & 0.680 & 0.982 & 0.911 & 0.889 \\
\hline F10 & 0.846 & & & & & & & - & 0.937 & 0.913 & 0.917 & 0.960 & 0.955 & 0.733 & 0.686 & 0.041 & 0.710 & 0.971 & 0.913 & 0.898 \\
\hline F11 & 0.840 & & & & & & & & - & 0.981 & 0.967 & 0.902 & 0.985 & 0.589 & 0.579 & 0.034 & 0.553 & 0.944 & 0.984 & 0.979 \\
\hline F12 & 0.830 & & & & & & & & & - & 0.976 & 0.888 & 0.955 & 0.536 & 0.545 & 0.023 & 0.519 & 0.919 & 0.990 & 0.979 \\
\hline F13 & 0.827 & & & & & & & & & & - & 0.889 & 0.955 & 0.570 & 0.530 & 0.026 & 0.509 & 0.914 & 0.974 & 0.976 \\
\hline F14 & 0.808 & & & & & & & & & & & - & 0.593 & 0.751 & 0.706 & 0.031 & 0.658 & 0.962 & 0.867 & 0.867 \\
\hline F18 & 0.831 & & & & & & & & & & & & - & 0.661 & 0.635 & 0.039 & 0.579 & 0.974 & 0.959 & 0.958 \\
\hline F19 & 0.604 & & & & & & & & & & & & & - & 0.693 & 0.081 & 0.783 & 0.732 & 0.533 & 0.534 \\
\hline F20 & 0.584 & & & & & & & & & & & & & & - & 0.074 & 0.662 & 0.686 & 0.562 & 0.545 \\
\hline F21 & 0.037 & & & & & & & & & & & & & & & - & 0.061 & 0.034 & 0.026 & 0.030 \\
\hline F22 & 0.559 & & & & & & & & & & & & & & & & - & 0.659 & 0.522 & 0.480 \\
\hline F23 & 0.846 & & & & & & & & & & & & & & & & & - & 0.915 & 0.899 \\
\hline F24 & 0.829 & & & & & & & & & & & & & & & & & & - & 0.982 \\
\hline F25 & 0.822 & & & & & & & & & & & & & & & & & & & - \\
\hline
\end{tabular}

Tabel 7. Nilai indeks overlap pada tiap provenan pada puncak pembungaan 2010 dan 2011 di Kebun Benih Paliyan.

\begin{tabular}{lcc}
\hline Provenan & \multicolumn{2}{c}{ Nilai indeks overlap } \\
\cline { 2 - 3 } Masarete, Buru & 2010 & 2011 \\
Rat gelombeng, Buru & 0.81 & 0.82 \\
Waipirit, Seram & 0.85 & 0.84 \\
Pelita Jaya, Seram & 0.82 & 0.83 \\
Cotonea, Seram & 0.83 & 0.84 \\
Suli, Ambon & 0.85 & 0.82 \\
Northern, Australia & 0.85 & 0.83 \\
Western, Australia & 0.63 & 0.59 \\
Gundih & 0.54 & 0.48 \\
\end{tabular}

Jika dilihat pada masing-masing provenan, provenan dari Australia bagian barat memiliki nilai indeks overlap yang paling rendah dibanding dengan provenan lain. Hal ini disebabkan karena selain produksi bunga yang rendah, juga karena waktu pembungaan yang tidak sinkron dengan provenan yang lain. 


\section{Implikasi sinkronisasi pembungaan dalam pengelolaan kebun benih.}

Periode pembungaan yang sinkron dan berlangsung dalam waktu lama di kebun benih kayuputih di Gunungkidul sangat mendukung untuk terjadinya perkawinan silang. Kartikawati et al., (2013) menyebutkan bahwa pola perkawinan kayuputih di kebun benih Paliyan adalah perkawinan silang dengan nilai tm sebesar 0,9. Dengan kontribusi individu berbunga lebih dari 75\% memberikan peluang perkawinan silang dengan banyak rekombinan gen. Dengan demikian potensi genetik yang ada dikebun benih tersebut dapat diwariskan dengan baik pada generasi berikutnya melalui produksi benih yang dihasilkan. Menurut Pinyopusarerk \& Hardwood (2003) menyebutkan bahwa apabila terdapat lebih dari $50 \%$ individu yang berbunga sinkron di kebun benih maka kebun benih tersebut dapat direkomendasikan untuk dipanen dan dimanfaatkan dalam penanaman skala luas.

Adanya famili dari Australia bagian barat yang waktu pembungaannya tidak sinkron dan produksi bunga yang rendah perlu diupayakan melalui aplikasi stimulasi pembungaan agar produksi bunga banyak dan pembungaan dapat sinkron dengan famili yang lain sehingga potensi genetik famili-famili tersebut dapat diwariskan pada benih yang dihasilkan. Pemberian hormon seperti paclobutrazole dapat diaplikasikan untuk jenis kayuputih (famili Myrtaceae). Pengaruh positif Paclobutrazole terhadap peningkatan produksi bunga dan buah telah terbukti pada beberapa jenis Eucalyptus, seperti E. urophylla, E. grandis, E. tereticornis, E. nitens serta pada jenis Melaleuca alternifolia (Moncur et al., 1994).

\section{KESIMPULAN}

Pola pembungaan di kebun benih kayuputih di Paliyan cenderung serentak (sinkron) yang ditunjukkan dengan jumlah pohon-pohon yang berbunga dan berkontribusi memproduksi benih relative besar (70-80\%). Nilai indeks overlapping yang tinggi $(>0,9)$ juga mengindikasikan besarnya peluang untuk terjadi perkawinan secara acak. Pembungaan puncak terjadi pada akhir Januari sampai awal bulan Februari dengan rentang waktu yang cukup lama, mulai November hingga Juni. Pembungaan yang sinkron ini sangat mendukung untuk terjadinya perkawinan silang secara acak sehingga potensi genetik yang ada di kebun benih dapat diwariskan dengan baik pada generasi berikutnya.

\section{UCAPAN TERIMA KASIH}

Penulis mengucapkan terima kasih kepada Prof. Na'iem, Dr. Eko Bhakti dan 
Dr. Anto Rimbawato atas bantuannya dalam menyusun karya tulis ini. Penulis juga mengucapkan banyak terimakasih kepada Sunaryanto dan Naryanto yang telah membantu mengoleksi data dari lapangan.

\section{DAFTAR PUSTAKA}

Burczyk, J., \& Chalupka, W. (1997). Flowering and cone production variability and its effect on parental balance in a scots pine clonal seed orchard. Ann. Sci. For., 54, 129-144.

Chaix, G., Vigneron. P., Razafimaharo. V., \& Hamon. S. (2007). Are phonological observations sufficient to estimate the quality of seed crops from a Eucalyptus grandis open- pollinated seed orchard? Consequences for seed collections. New Forest, 33, 41-52.

Chen, Y.Y., \& Hsu, S. B. (2011). Synchronized reproduction promotes species coexistence through reproductive facilitation. Journal of Theoretical Biology, 274, 136-144.

Crawley, M. J. (1997). Plant Ecology (2nd ed.). Oxford: Blackwell Science.

Dinas Pertanian Tanaman Pangan dan Perikanan. (2010). Data Curah hujan Kabupaten Gunungkidul (tidak dipublikasikan). Gunungkidul.

El-Kassaby, Y. A. (2000). Effect of forest tree domestication on gene pools. In A. Young, D. Boshier \& T. Boyle (Eds.). Forest Conservation Genetics, Principle and Practice. (pp. 197-213). CSIRO Publishing.

Ertekin, M. (2010). Clone Fertility and Genetic Diversity in a Black Pine Seed Orchard. Silvae Genetica, 59(4), 145-150.

Ghazoul, J. (1997). Field Studies of Forest Tree Reproductive Ecology. ASEAN-Canada Forest Tree Seed Center Project, Muaklek, Saraburi, Thailand.

Gomory, D., Bruchanick, R., \& Longauerc, R. (2003). Fertility variation and flowering asynchrony in Pinus sylvestris: consequences for the genetic structure of progeny in seed orchards. Forest Ecology and Management, 174, 117-126.
Griffin, A. R., \& Sedgley, M. (1989). Sexual Reproduction of Tree Crops. San Diego, USA: Academic Press Inc. Harcourt Brace Jovanovich Publisher.

Gunaga , R. P., \& Vasudeva, R. (2009). Overlap Index : A Measure to Access Flowering Synchrony Among teak (Tectona granndis Linn.f) Clone in Seed Orchards. Current Science, 97(6), 941-946.

Jones, C. E., \& Little, R. J. (1983). Handbook of Experimental Pollination Biology. New York: Van Nostrand Reinhold Co. Inc.

Kang, K. S., \& Lindgren, D. (1998). Fertility variation and its effect on the relatedness of seeds in Pinus densiflora, $P$. thunbergii and $P$. koraiensis clonal seed orchards. Silvae Genetica, 47, 196-200.

Kartikawati. N. K, Naiem., M, Hardiyanto, E. B \& Rimbawanto, A. (2013). Improvement of Seed Orchard Management Based On Mating System of Cajuputi trees. Indonesian Journal of Biotechnology, $18(1), 13-22$.

Kaya, N., Isik, K. \& Adams, W. T. (2006). Mating system and pollen contamination in a Pinus brutia seed orchard. New Forests, 31, 409-416.

Larcher, P. (1997). Physiological plant ecology. New York: John Wiley \& Sons Inc.

Levy, Y. Y., \& Dean, C. (1998). The transition to flowering. Plant Cell, 10, 1973-1990.

Mahoro, S. (2002). Individual flowering schedule, fruit set and flower and seed production in Vaccinium hirtum Thunmb (Ericaceae). Canadian Journal of Botany, 80, 82-92.

Moncur M. W., \& Bolland D. J. (2000). Production of genetically improved Eucalyptus nitens seed for reforestation. Australian Forestry, 63, 211-217.

Moncur, M. W., Rasmussen, G. F., \& Hasan, O. (1994). Effect of Paclobutrazol on Flower Bud Production in Eucalyptus nitens Espalier Seed Orchards. Canadian Journal of Forest, 24, 46-49.

Opik H., \& Rolfe, S. A. (2005). The Physiology of Flowering Plants. Cambridge.

Owens, J. N., Somsathapornkul, P., \& Tangmitcharon, S. (1991). Manual Studying Flowering and Seed Ontogeny in Tropical Forest Trees. ASEAN-Canada Tree Seed Centre. Muak-Lek Saraburi 18180, Thailand. 
Pinyopusarerk, K., \& Harwood, C. E. (2003).

Flowering and seed production in tropical Eucalyptus seed orchard. In J.W. Turnbull (Ed). Eucalyptus in Asia. ACIAR Proceeding No 111. Australian Centre for International Agricultural Research (pp. 247-248). Canberra.

Susanto, M., Doran. J. C., Arnold, R., \& Rimbawanto, A. (2003). Genetic variation in growth and oil characteristics of Melaleuca cajuputi subsp. cajuputi and potential for genetic improvement. Journal of Tropical Forest Science, 15(3), 469-482.

Susanto, M., Rimbawanto, A., Prastyono, \& Kartikawati, N.K. (2008). Peningkatan genetik pada Melaleuca cajuputi subsp. Cajuputi. Jurnal Pemuliaan Tanaman Hutan, 2(2), 1-10.

Varghese, M., Kamalakannan, R., Harwood, C. E., Lindgren, D., \& Mc.Donald, M. W. (2009). Changes in growth performance and fecundity of Eucalyptus camadulensis and E. tereticornis during domestication in southern India. Tree Genetics \& Genomes, 5, 629-640. 
Jurnal Pemuliaan Tanaman Hutan

Vol 9 No. 2, September 2015, 103-115 